Dhaka Univ. J. Biol. Sci. 25(1): 19-25, 2016 (January)

\title{
DISTRIBUTION OF ZINC FRACTIONS IN RELATION TO PROPERTIES OF SOME SOILS OF BANGLADESH
}

\author{
Kalpana Begum, Md. Faruque Hossain ${ }^{1}$ and Zakia Parveen* \\ Department of Soil, Water \& Environment, University of Dhaka, Dhaka 1000, Bangladesh
}

Key words: Distribution, Zinc fractions, Speciation procedure

\begin{abstract}
An investigation was conducted to determine the distribution and concentrations of different forms of $\mathrm{Zn}$ in the soils of Gazipur. Gerua, Kalma and Khilgaon soil series were identified in three land types, named as highland, medium high land and medium low land, respectively. Soil samples were collected from each soil series at three different depth such as surface $(0-15 \mathrm{~cm})$, subsurface $(15-40 \mathrm{~cm})$ and substratum $(40 \mathrm{~cm}+)$ to determine soil characteristics and the distribution pattern of $\mathrm{Zn}$ fractions. Results indicated that amount of total $\mathrm{Zn}$ varied significantly, ranges from 14.99 to $36.11 \mu \mathrm{g} / \mathrm{g}$ at different depth of different land types. Moreover, the purpose of the sequential extraction or fractionation was to find out the $\mathrm{Zn}$ in the exchangeable (Exch.), organic matter (Org.) bound, Mn oxide (Mn-O), amorphous Fe oxide (Am. Fe-O), crystalline Fe oxide (Crys. Fe-O) and residual (Res.) fractions. In Gerua, Kalma and Khilgaon soils, Zn concentrations predominated in Res. followed by Crys. Fe-O and Am. Fe-O fractions. Results reflected that soil properties influence the distribution of different $\mathrm{Zn}$ fractions in soils.
\end{abstract}

\section{Introduction}

Zinc is a heavy metal of much interest since it is a plant micronutrient as well as a potential contaminant in soils. Zinc in high concentrations can be toxic to flora and fauna, a subject of current environmental research ${ }^{(1)}$. Total $\mathrm{Zn}$ in soils indicates the potential capacity of soils to supply $\mathrm{Zn}$ for crop production given the capacity of crop to exploit it. However, total $\mathrm{Zn}$ in soil does not indicate $\mathrm{Zn}$ availability to plants. Availability of $\mathrm{Zn}$ for plants is reported to be associated with the distribution of this nutrient into fractions in soils and these fractions can be measured in order to understand how this metal influences the environment, is important to distinguish between the total quantities in the soil and the amounts that can be transferred into more soluble forms, becoming bioavailable.

*Author for correspondence: <zakiaparveen1@yahoo.ca>. ${ }^{1}$ American International UniversityBangladesh, Kemal Ataturk Avenue, H 58/B, Rd 21, Banani, Dhaka 1213, Bangladesh. 
The bio-available fraction is most crucial for assessing the environmental quality and possible health risk (2). Therefore, understanding of the distribution of $\mathrm{Zn}$ fractions in soils will help to characterize the behaviour of $\mathrm{Zn}$ in soils and possibly its availability for plant uptake.

The soil is a dynamic system where changes in its properties, management and environmental factors affect the availability of metals(3). However, distribution of $\mathrm{Zn}$ varies significantly in response to soil properties(4). The distribution of microelements among fractions in soils is influenced by several properties like $\mathrm{pH}$, organic matter, CEC and soil texture(5, ${ }^{(5)}$.

Zinc is a transition element and is able to form complexes with a variety of organic ligands, interacts with organic matter, and both soluble and insoluble Zn-organic complexes are formed. In soil solution, the speciation of $\mathrm{Zn}$, and thus the free $\mathrm{Zn}$ activity determines the availability of $\mathrm{Zn}$ for plants as a micronutrient and its characteristics as a heavy metal contaminant. The solubility of $\mathrm{Zn}$ in soil solution must be quantified to evaluate bioavailability and transport of $\mathrm{Zn}$ in soils ${ }^{(7)}$. Kabata-Pendias and Pendias ${ }^{(8)}$ have stated that chemistry of $\mathrm{Zn}$ is governed by the $\mathrm{pH}$ of the soil. In acidic soil, $\mathrm{Zn}$ adsorption is related to cation exchange sites ${ }^{(8)}$. While in alkaline soils the chemistry is dominated by organic ligands. In more alkaline soils $\mathrm{Zn}$ can form an organo-zinc complex, which would also increase the metals mobility. Thus, the aim of this research was to determine the total concentration of $\mathrm{Zn}$ and its fractions using a speciation procedure in Madhupur Tract soils and to assess the correlation between the zinc content, its fractions and physical, chemical and physico-chemical properties of soils.

\section{Materials and Methods}

The sampling site is located about $24^{\circ} 01^{\prime}$ and $24^{\circ} 21^{\prime}$ North Latitude and $90^{\circ} 18^{\prime}$ and $90^{\circ} 33^{\prime}$ Longitude of village Bangnahati, post Kewabazar, Upazila: Sreepur, district Gazipur. Composite soil samples at the rate of three per location were collected from three different land types (Gerua-high land, Kalma-medium high land and Khilgaonmedium low land) at a depth of surface $(0-15 \mathrm{~cm})$, subsurface $(15-40 \mathrm{~cm})$ and substratum $\left(40^{+} \mathrm{cm}\right)$.

Soil samples were air-dried, ground by wooden hammer and passed through $2 \mathrm{~mm}$ stainless steel sieve. Bulk density, particle size analysis, moisture \%, CEC and $\mathrm{pH}$ were determined following standard methods ${ }^{(9)}$. The organic matter of the soils was determined by wet oxidation following the method of Walkley and Black ${ }^{(10)}$. Total concentration of $\mathrm{Fe}, \mathrm{Mn}, \mathrm{Zn}$ and $\mathrm{Cu}$ in soil was analyzed by digesting soil with aquaregia at a ratio of $1: 10$. Total $\mathrm{Fe}, \mathrm{Mn}, \mathrm{Zn}$ and $\mathrm{Cu}$ were estimated by AAS (Atomic Absorption Spectrophotometer) ${ }^{(9)}$. The $\mathrm{Zn}$ fractionation procedure was largely based on the method of Shuman ${ }^{(11)}$. The results were statistically analyzed using Stata software. 


\section{Results and Discussion}

The $\mathrm{pH}$ of the investigated soils was moderately acidic, indicating that the soil was acidic in reaction, $\mathrm{pH}$ gradually increases from the upper to the lower layers (Table 1), because when rain falls on the surface layers of high land or medium highland, the positive $\mathrm{H}^{+}$ions of rain water replaces the other cations in the soil profile, which accumulates in the lower layers by leaching and thus $\mathrm{pH}$ increases in the lower layers, as a result mobilization of micro elements take place. Higher is the bulk density lower is the organic matter content. The increasing trend of bulk density from top to bottom indicated organic matter content gradually decreased from high land to medium low land. Among the soils the organic matter concentrations were higher in surface soils for each land type than the subsurface or substratum may be due to the accumulation of plant residues and household wastes.

Table 1. Some physico-chemical characteristics of Gerua, Kalma and Khilgaon soils.

\begin{tabular}{llcccccc}
\hline Soils & Layer & $\mathrm{pH}$ & $\begin{array}{c}\mathrm{BD} \\
(\mathrm{g} \mathrm{cm})\end{array}$ & $\begin{array}{c}\text { CEC } \\
(\mathrm{meq} / 100 \mathrm{~g})\end{array}$ & $\begin{array}{c}\mathrm{OM} \\
(\%)\end{array}$ & $\begin{array}{c}\text { Clay } \\
(\%)\end{array}$ & Texture \\
\hline \multirow{4}{*}{ Gerua } & Surface & 4.75 & 1.13 & 5.96 & 1.84 & 25 & Silt loam \\
& Subsurface & 5.29 & 1.32 & 7.48 & 0.73 & 36 & Silty clay loam \\
& Substratum & 4.79 & 1.54 & 9.29 & 0.355 & 36 & $"$ \\
& Surface & 5.54 & 1.28 & 3.97 & 2.39 & 20 & Silt loam \\
\multirow{6}{*}{ Kalma } & Subsurface & 5.28 & 1.71 & 3.975 & 0.605 & 27 & Silty clay loam \\
& Substratum & 5.34 & 1.19 & 6.31 & 0.355 & 35 & $"$ \\
& Surface & 5.16 & 1.39 & 6.31 & 1.81 & 30 & $"$ \\
& Subsurface & 5.14 & 1.35 & 5.025 & 0.85 & 33 & $"$ \\
& Substratum & 5.88 & 1.53 & 11.105 & 0.48 & 47 & Silty clay \\
\hline
\end{tabular}

Fine textured soils increases from surface to substratum for each soil profile, from highland to medium high land, medium highland to medium low land due to clay accumulation by leaching in the bottom layers heavier textures were observed in the lower layers. The total and available $\mathrm{Zn}$ gradually decreased in the lower layers, as soil $\mathrm{pH}$ increased, the solubility and availability of Zn decreased ${ }^{(12)}$. However, CEC gradually increases from upper layers to the lower layers, also affected the availability, because greater CEC means lower availability as cations were adsorbed by the clay particles.

The mean concentrations of $\mathrm{Zn}$ fractions in the soils are presented in the Table 2.

The exchangeable form of $\mathrm{Zn}$ represents the most readily available source ranged from 0.21 to $1.05 \mu \mathrm{g} / \mathrm{g}$ of the total concentration. The surface of Gerua soil contained the higher exchangeable $\mathrm{Zn}$ compared to other soils which reflects the situation of increases solubility of $\mathrm{Zn}$ at low $\mathrm{pH}^{(13,14)}$. The $\mathrm{pH}$ value of surface soils of Gerua was 4.75, while the 
$\mathrm{pH}$ value of substratum soils of Khilgaon was 5.88. As the $\mathrm{pH}$ increased down to the profile, $\mathrm{Zn}$ concentration decreased.

Table 2. Distribution of different Zn fractions and total Zn in Gerua, Kalma and Khilgaon soils.

\begin{tabular}{|c|c|c|c|c|c|c|c|c|}
\hline \multirow[b]{2}{*}{ Soils } & \multirow[b]{2}{*}{ Layer } & \multicolumn{7}{|c|}{ Zn Concentration $\left(\mu \mathrm{g} \mathrm{g}^{-1}\right)$} \\
\hline & & Exch. & $\begin{array}{c}\text { Org. } \\
\text { bound }\end{array}$ & $\mathrm{Mn}-\mathrm{O}$ & Am.Fe-O & $\begin{array}{l}\text { Crys. } \\
\text { Fe-O }\end{array}$ & Res. & $\begin{array}{c}\text { Total } \\
\mathrm{Zn} \\
\end{array}$ \\
\hline \multirow{3}{*}{ Gerua } & Surface & 1.05 & 1.02 & 0.99 & 6.09 & 5.76 & 20.99 & 33.04 \\
\hline & Subsurface & 0.26 & 0.44 & 0.45 & 1.99 & 5.69 & 20.52 & 29.04 \\
\hline & Substratum & 0.27 & 0.96 & 0.26 & 3.01 & 7.27 & 27.3 & 36.11 \\
\hline \multirow{3}{*}{ Kalma } & Surface & 0.53 & 1.41 & 0.68 & 4.23 & 3.47 & 11.58 & 20.48 \\
\hline & Subsurface & 0.21 & 0.65 & 1.47 & 1.29 & 1.14 & 10.41 & 14.99 \\
\hline & Substratum & 0.26 & 0.44 & 0.69 & 5.14 & 3.36 & 13.83 & 24.12 \\
\hline \multirow{3}{*}{ Khilgaon } & Surface & 0.72 & 0.59 & 0.67 & 3.11 & 5.54 & 13.24 & 22.44 \\
\hline & Subsurface & 0.24 & 1.32 & 0.65 & 8.19 & 2.47 & 9.26 & 20.6 \\
\hline & Substratum & 0.45 & 0.45 & 0.17 & 3.24 & 1.91 & 19.94 & 25.96 \\
\hline
\end{tabular}

The correlations between $\mathrm{Zn}$ and soil properties are presented in Table 3. $\mathrm{pH}$ shows negative but not significant relationship with Exch. Zn fraction. Similar result was found by others ${ }^{(15)}$. Bulk density shows negative significant relationship at $\mathrm{p}<0.01 \%$ levels with Exch. Zn fraction it might be due to high bulk density reduces the exchange sites of the soils and organic matter shows positively significant relationship with Exch. fraction at $\mathrm{P}<0.01 \%$ levels indicated complex formation generated by organic matter, promote $\mathrm{Zn}$ availability in soils (Table 3 ) and findings are very similar to the several works ${ }^{(5,16,17)}$. Availability of $\mathrm{Zn}$ increased with increasing organic matter. $\mathrm{pH}$, clay and CEC show negative but very poor relationship with Exch. fraction, the results are in disagreement with others ${ }^{(5)}$.

The amount of $\mathrm{Zn}$ in organically bound form was highest in the surface soils of Kalma soil. The share of $\mathrm{Zn}$ bound with organic matter in the analyzed soil samples was higher in the surface soils of Kalma soils than the surface soils of Gerua and Khilgaon soils because organic matter was highest $(2.39 \%)$ so organically bound zinc was highest $(1.41 \mu \mathrm{g} / \mathrm{g})$ in the surface soils. The relationship between soil organic matter and Org. bound $\mathrm{Zn}$ was indicated by the significant positive correlation at $\mathrm{p}<0.01 \%$ level (Table $3)$.

Values of Mn-O bound $\mathrm{Zn}$ ranged from 0.17 to $1.47 \mu \mathrm{g} / \mathrm{g}$ soil, while the highest value is recorded in subsurface layer of Kalma soils (Table 2). Zinc was higher in the crystalline Fe-oxide fraction than in the Mn-oxide fraction, indicating that $\mathrm{Zn}$ is more associated with Fe-oxide than Mn-oxides which might be the simple predominance of the Fe oxide 
fraction(11). Correlation coefficient between the $\mathrm{Zn}$ associated with $\mathrm{Mn}-\mathrm{O}$ fraction and both the clay and CEC showed that Mn-O bound $\mathrm{Zn}$ and clay or Zn and CEC were significantly correlated with each other at $\mathrm{p}<0.01 \%$ levels. The relationship in each case is negative. $\mathrm{Mn}-\mathrm{O}$ also shows negative significant relationship with total $\mathrm{Zn}$ concentration at $\mathrm{p}<0.01 \%$ level (Table 3 ).

Table 3. Relationship between individual Zn fractions and soil properties.

\begin{tabular}{|c|c|c|c|c|c|c|}
\hline \multirow{2}{*}{$\begin{array}{l}\text { Zinc } \\
\text { fractions } \\
(\mu \mathrm{g} / \mathrm{g})\end{array}$} & \multicolumn{6}{|c|}{ Soil Properties } \\
\hline & $\mathrm{pH}$ & $\begin{array}{c}\text { Bulk density } \\
\qquad\left(\mathrm{g} / \mathrm{cm}^{3}\right)\end{array}$ & $\begin{array}{l}\text { Clay } \\
(\%)\end{array}$ & $\begin{array}{c}\text { CEC } \\
\text { (meq/100g) }\end{array}$ & $\begin{array}{l}\mathrm{OM} \\
(\%)\end{array}$ & $\begin{array}{c}\text { Total Zn } \\
(\mu \mathrm{g} / \mathrm{g})\end{array}$ \\
\hline Exch. & -0.2888 & $-0.5020^{* *}$ & -0.3737 & -0.0496 & $0.7221^{* *}$ & 0.3152 \\
\hline Org. & -0.0359 & -0.0941 & -0.3498 & -0.2248 & $0.4398^{* *}$ & -0.0334 \\
\hline $\mathrm{Mn}-\mathrm{O}$ & -0.2250 & 0.0864 & $-0.6439^{* *}$ & $-0.7344^{* *}$ & 0.2078 & $-0.5211^{* *}$ \\
\hline Am. Fe-O & -0.2386 & $-0.6097^{* *}$ & -0.1452 & -0.2192 & 0.1997 & 0.0463 \\
\hline Cryst. Fe-O & $-0.6694^{* *}$ & -0.3386 & -0.0717 & 0.2517 & 0.1730 & $0.8227^{* *}$ \\
\hline Res. & -0.3308 & 0.0063 & $0.4249^{*}$ & $0.7225^{* *}$ & -0.2718 & $0.9227^{* *}$ \\
\hline
\end{tabular}

*Indicates at $0.05 \%$ and ${ }^{* *} 0.01 \%$ level of significance.

Crystalline Fe-O bound $\mathrm{Zn}$ was much higher than Am. Fe-O bound $\mathrm{Zn}$ except the surface and subsurface soils of Kalma soil series (Table 2). Nair and Cottenie ${ }^{(18)}$ reported that the amorphous $\mathrm{Fe}_{2} \mathrm{O}_{3}$ possibly retain a large proportion of the trace elements by surface coating finer particles. The relationship between soil $\mathrm{pH}$ and Crys. Fe-O content showed a significantly negative correlation at $\mathrm{p}<0.01 \%$ levels and between Crys. Fe-O and total $\mathrm{Zn}$ concentration the relationship indicated a positively significant relationship at $0.01 \%$ level (Table 3 ).

In all the studied soils, $\mathrm{Zn}$ was mostly concentrated in the residual fraction. A considerable amount of $\mathrm{Zn}$ was found in residual fraction where possibly most of the total $\mathrm{Zn}$ was held within the silicate minerals ${ }^{(19)}$. Among these soils the residual fraction of $\mathrm{Zn}$ was found highest in the substratum layer of Khilgaon soil that means the lowest layer of the studied soil. The $\mathrm{Zn}$ was highest in the residual fraction than the other fractions of all soils. Residual fraction showed positive and significant relationships with clay at $\mathrm{p}<0.05 \%, \mathrm{CEC}$ at $\mathrm{p}<0.01 \%$ and with total $\mathrm{Zn}$ concentration at $\mathrm{p}<0.01 \%$ (Table 3 ). Another study of the $\mathrm{Zn}$ fractions reported up to $70 \%$ of $\mathrm{Zn}$ in agricultural soils in the residual fraction and nearly all the remainder associated with Fe oxides ${ }^{(20)}$.

A sequential extraction technique used to characterize bonding of metals to the soils showed close association between fractions of studied elements and soil properties. It also indicated the preferential reduction of total $\mathrm{Zn}$ concentration towards the lower depths of soils, due to comparatively high $\mathrm{pH}$. In case of total $\mathrm{Zn}$ the concentration 
decreased towards the lower depths, the Exch. and Org. bound Zn were also decreased. In all soils, Zn concentration dominated in Crys. and Am. Fe-O fractions.

Distributions of micro elements among chemical fractions are generally dependent on the total concentration of micro elements and soil properties. The values of soil properties were different in three land types, which clearly reflected that soil properties influenced the distribution of different $\mathrm{Zn}$ fractions in soils.

\section{References}

1. Barbarick KA, JA Ippolito and DG Westfall 1997. Sewage biosolids cumulative effects on extractable-soil and grain elemental concentrations. J. Environ. Qual. 26: 1696-1702.

2. Madejon E, P Madejon, P Burgos, A Perez de Mora and F Cabrera 2009. Trace elements, pH and organic matter evolution in contaminated soils under assisted natural remediation: A 4year field study. J. Hazardous Materials 162: 931-938.

3. Alloway BJ 1995. Heavy Metals in Soils. Blackie Academic \& Professional, Chapman \& Hall, Glasgow, UK. pp. 368.

4. Adhikari T and RK Rattan 2007. Distribution of zinc fractions in some major soils of India and the impact on nutrition of rice. Commun. Soil Sci. and Plant Anal. 38: 2779-2798.

5. Ibrahim AK, A Usman, B Abubakar and UH Aminu 2011. Extractable micronutrients status in relation to other soil properties in Billiri Local Government Area. J. Soil Sci. Environ. Manag. 3: 282-285.

6. Ramzan S, MA Bhat, NA Kirmani and R Rasool 2014. Fractionation of zinc and their association with soil properties in soils of Kashmir Himalayas. Ind. J. Agric. Soil Sci. 2: 132-142.

7. Catlett KM, DM Heil, WL Lindsay and MH Ebinger 2002. Effects of soil chemical properties on Zinc ${ }^{2+}$ activity in 18 Colarado soils. Soil Sci. Soc. Am. J. 66: 1182-1189.

8. Kabata-Pendias A and H Pendias 2001. Trace Elements in Soils and Plants. CRC Press, Boca Raton, FL. pp. 260-267.

9. Jackson ML 1962. Soil Chemical Analysis. New York, Prentice-Hall Inc. pp. 498.

10. Walkley A and IA Black 1934. An examination of Degtjareff method for determining soil organic matter and a proposed modification of the chromic acid titration method. Soil Sci. 37: 29-37.

11. Shuman LM 1985. Fractionation method for soil micro elements. Soil Sci. 140: 11-22.

12. Hart J, M Mellbye, WC Young III and T Silberstein 2003. Nutrient Management for Annual Ryegrass Grown for Seed. Nutrient Management Guide. Oregon State University Extension Service, Corvallis, Western Oregon. USA. pp. 1-8.

13. Kalembasa D and K Pakula 2006. Fractions of zinc and copper in the forest luvisols of the south podlaise lowland. Pol. J. Environ. Stud. 15: 98-103.

14. Kucharzewski A, L Nowak and M Dabowski 2004. Influence of some soil properties on the content of $\mathrm{Zn}, \mathrm{Cu}$ and $\mathrm{Mn}$ soluble and total forms in soils of the lower Silesia. Zesz. Probl. Post. NaukRol. 502: 189-206.

15. Szabo G and K Czeller 2009. Examination of the heavy metal uptake of carrot (Daucus carota) in different soil types. AGD Landscape and Environ. 3: 56-70. 
16. Elbordiny MM and YC El-Dewiny 2008. Effect of some salt affected soil properties on micro nutrients availability. Appl. Sci. J. Res. 4: 1569-1573.

17. Verma VK, RK Setia, PL Sharma, S Charanjit and A Kumar 2005. Pedospheric variations in distribution of DPTA - extractable micronutrients in soils developed on different physiographic units in central parts of Punjab, India. Int. J. Agric. Biol. 7: 243-246.

18. Nair KPP and A Cottenie 1971. A statistical evaluation of the interrelationships between particle size fractions. Free iron oxide and trace elements. Soil Sci. 22: 203-209.

19. Rouf MA, Z Parveen and S Rahman 1998. Distribution and fractionation of zinc, copper, iron and manganese in some selected surface soils in Bangladesh. J. Asiat. Soc. Bangladesh Sci. 24: 35-45.

20. Shuman LM 1979. Zinc, manganese, and copper in soil fractionations. Soil Sci. 127:10-17.

(Manuscript received on 20 August, 2015; revised on 3 January, 2016) 